This is an electronic reprint of the original article. This reprint may differ from the original in pagination and typographic detail.

Author(s): Poosakkannu, Anbu; Nissinen, Riitta; Männistö, Minna; Kytöviita, Minna-Maarit

Title: $\quad$ Microbial community composition but not diversity changes along succession in arctic sand dunes

Year: $\quad 2017$

Version:

Please cite the original version:

Poosakkannu, A., Nissinen, R., Männistö, M., \& Kytöviita, M.-M. (2017). Microbial community composition but not diversity changes along succession in arctic sand dunes. Environmental Microbiology, 19(2), 698-709. https://doi.org/10.1111/14622920.13599

All material supplied via JYX is protected by copyright and other intellectual property rights, and duplication or sale of all or part of any of the repository collections is not permitted, except that material may be duplicated by you for your research use or educational purposes in electronic or print form. You must obtain permission for any other use. Electronic or print copies may not be offered, whether for sale or otherwise to anyone who is not an authorised user. 


\section{Microbial community composition but not diversity changes along succession in arctic sand}

\section{dunes}

Anbu Poosakkannu*${ }^{1}$, Riitta Nissinen ${ }^{1}$, Minna Männistö ${ }^{2}$, Minna-Maarit Kytöviita ${ }^{1}$

1) Department of Biological and Environmental Science, PO Box 35, FI-40014 University of Jyväskylä, Finland.

2) Natural Resources Institute Finland, P.O. Box 16, FI-96301 Rovaniemi, Finland.

*Corresponding author: Anbu Poosakkannu, Department of Biological and Environmental

Science, PO Box 35, FI-40014 University of Jyväskylä, Finland. Tel +358 (0)466137555 and

Fax+358(0)14 617 239. Email: anbu.a.poosakkannu@jyu.fi.

\section{Running title: Deschampsia flexuosa associated microbiomes}

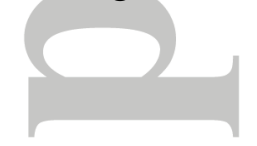

Originality-Significance Statement: We believe this is one of the few studies on plant-associated bacteria and fungi (combined) in cold environments and the first on primary succession.

Furthermore, this work is one of the very few on arctic microbial endophytes in belowground and aboveground plant parts. We show that fungi and bacteria may not follow the same successional trajectories.

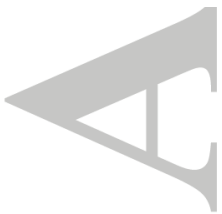

This article has been accepted for publication and undergone full peer review but has not been through the copyediting, typesetting, pagination and proofreading process which may lead to differences between this version and the Version of Record. Please cite this article as an 'Accepted Article', doi: 10.1111/1462-2920.13599 


\section{Summary}

We tested the generality of increasing diversity of fungi and bacteria along arctic sand dune succession. Microbial communities were examined by high-throughput sequencing of 16S rRNA genes (bacteria) and internal transcribed spacer (ITS) regions (fungi). We studied four microbial compartments (inside leaf, inside root, rhizosphere and bulk soil) and characterized microbes associated with a single plant species (Deschampsia flexuosa) across two sand dune successional stages (early and late). Bacterial richness increased along succession in bulk soil and leaf endosphere. In contrast, soil fungal richness remained constant while root endosphere fungal richness increased along succession. There was, however, no significant difference in Shannon diversity indices between early and late successional stage in any compartments. There was a significant difference in the composition of microbial communities between early and late successional stage in all compartments, although the major microbial OTUs were shared between early and late successional stage. Co-occurrence network analysis revealed successional stagespecific microbial groups. There were more co-occurring modules in early successional stage than in late stage. Altogether, these results emphasize that succession strongly affects distribution of microbial species, but not microbial diversity in arctic sand dune ecosystem and that fungi and bacteria may not follow the same successional trajectories. 


\section{Introduction}

Vegetation succession is one of the oldest theoretical concepts in ecology (e.g. Cowles, 1899). It is generally conceived that in progressive ecosystem succession, the number of plant (Bazzaz, 1975) and animal species (Tews et al., 2004) and amount of soil organic matter increases with time (Berendse et al., 1998, Walker and del Moral, 2003; Chapin et al., 1994). In soil, the number of microbial taxa (richness), their abundance, and a combined measure of richness and the evenness of their abundance (diversity) have been shown to increase along a successional trajectory from early successional stages to later ones (Nemergut et al., 2007; Brown and Jumpponen, 2014; Brown and Jumpponen, 2015). These studies mainly focused on vegetated or non-vegetated soil microbial succession. However, microbes have the ability to colonize different plant parts for nutritional (Belnap and Lange, 2003) or non-nutritional (Diaz et al., 1993) purposes. Nevertheless, comparisons of plant-associated microbial successional dynamics are rare (Blaalid et al., 2012) and could elucidate whether the general concept of increasing species richness and diversity along successional trajectory is also applicable to microbial communities.

Microbial communities that live in close association with plants are known as plant-associated microbiomes. The plant microbiome can be divided into external (phyllosphere, rhizosphere) and internal (endosphere) compartments. Many of the plant-associated microbes are known to have various beneficial effects on host plants (Berg et al., 2014; Bardgett and Chan, 1999; Kumari, 2016; Wilson, 1940; Yang et al., 2009). Plant-associated microbial diversity and community composition (abundance and identity of taxa) are affected by compartment, host genotype, sampling location, and season, but the effect of these factors varies between different studies 
(Gottel et al., 2011; Bulgarelli et al., 2012; Peiffer et al., 2013; Bulgarelli et al., 2015; Edwards et al., 2015; Coleman-Derr et al., 2016).

Soil is traditionally considered to be the source of rhizosphere microbes (Berg and Smalla, 2009; Normander and Prosser, 2000; Philippot et al., 2013; Singh et al., 2007) and, in turn, rhizosphere as the source of endosphere microbes (Bulgarelli et al., 2012; Edwards et al., 2015; Long et al., 2008; Lundberg et al., 2012). If plant-associated microbes are horizontally acquired from the soil as is frequently argued, successional changes in soil microbial communities should be reflected in plant-associated microbial community. However, it has recently been shown that a significant portion of the root endosphere microbes (Johnston-Monje et al., 2014; Johnston-Monje and Raizada 2011), and a few of the rhizosphere microbes (Johnston-Monje and Raizada 2011; Hardoim et al. 2012; Puente et al. 2009) are vertically inherited through seed. Consequently, if the plant-associated microbiome is to a large extent vertically inherited, its community composition should be relatively constant along a successional gradient.

Co-occurrence of plant-associated microbes has been rarely studied and the few studies mainly focus on prokaryotic microbes (Cardinale et al., 2015; Edwards et al., 2015). Furthermore, there has been little attention on fungi-fungi and inter-kingdom relationships such as bacteria-fungi coexisting in environmental samples. Facilitative interactions between plants are more important in early than late successional stage (Bertness and Callaway, 1994; Brooker and Callaghan, 1998). Similarly, positive intra or inter-kingdom interactions may also be of particular importance in nutrient limited early succession stage co-occurring microbial communities as they are likely to exchange metabolites and nutrients for survival (Frey-Klett et al., 2011; Zelezniak et 
al., 2015). Ecologically important co-occurrence patterns in microbial systems help to identify potential biotic interactions, habitat limitation and physiological similarity (Barberán et al., 2012;

Williams et al., 2014).

Based on the current knowledge on ecosystem succession, we hypothesized that soil and plantassociated microbes could follow the same trajectories as other organisms (e.g. Bazzaz, 1975, Walker and del Moral, 2003). We chose Deschampsia flexuosa as a focal plant species because of its ecological importance in circumboreal ecosystems. In the present study, we tested the following predictions in arctic sand dune primary succession ecosystem: (i) plants and soil contain more numerous microbial species in late successional stage than in early successional stage (ii) the successional stage of the ecosystem affects microbial community composition significantly and (iii) co-occurring microbes are successional stage specific.

\section{Results}

\section{High-throughput sequencing of 16S rRNA (bacteria) genes and ITS regions (fungi)}

We investigated microbial communities of bulk soil, rhizosphere soil, and D. flexuosa leaf and root endosphere. These are collectively referred to as "compartment" hereafter. We collected compartment samples from early successional stage (monospecific D. flexuosa stands) and late successional stage (D. flexuosa stands together with other plant species) of arctic inland aeolian sand dunes in four different areas between 150 and 2250 meters distance apart (Figure 1). These areas are referred to as 'block' hereafter. Within each block, the distance between early and late successional stage was 10-20 meters. We examined microbial community diversity and composition by ion torrent sequencing of $16 \mathrm{~S}$ rRNA (bacteria) genes and internal transcribed 
spacer (ITS) regions (fungi). Altogether, we obtained 334,382 bacterial and 470,567 fungal good quality sequences. In one sample, there was between 1,701 and 12,831 bacterial sequences and between 1,304 and 11, 613 fungal sequences. A total of 20 bacterial and 5 fungal phyla were found across four compartments and two successional stages (Supplementary figures:

Supplementary figure 1).

\section{Microbial species richness but not Shannon diversity was moderately affected by succession}

To gain insights into the effect of succession on microbial species richness, we compared the observed and estimated OTU richness of the communities retrieved from early and late successional stage bulk soil, rhizosphere and the endosphere compartments. A global trend of higher mean microbial OTU richness (observed and estimated) was observed in late successional stage compartments in comparison to early successional stage (Table 1). Out of the eight comparisons, the OTU richness was significantly higher $(\mathrm{P}<0.05)$ in late successional stage when compared to early in bulk soil bacteria, leaf bacterial endosphere and fungal root endosphere compartments (Supplementary file1: Richness). The distance between sampling sites (i.e., block) had no effect on microbial taxa richness ( $\mathrm{P}>0.05$; Supplementary file1: Richness).

There were no significant differences observed in Shannon diversity indices between early and late successional stage in any compartment ( $\mathrm{P}>0.05$; Supplementary file1: Richness). Also, there were no significant differences in Shannon diversity indices $(\mathrm{P}>0.05)$ between different blocks (Supplementary file1: Richness). 


\section{Microbial community composition was primarily affected by succession}

Unconstrained principal coordinate analyses (PCoAs) were used to identify clustering pattern of microbial communities. The PCoAs were performed using both abundance (Weighted PCoAs) and the presence/absence data (Unweighted PCoAs). We performed PCoAs for each individual compartment separately to observe the microbial community clustering pattern according to the successional stage. In all the compartments, both weighted and unweighted PCoAs (data not shown) microbial (both bacteria and fungi) communities clustered strongly according to successional stage (Figure 2.1 and Figure 2.2). Permutational Multivariate Analysis of Variance (PERMANOVA) confirmed that the observed clustering patterns in PCoAs were statistically significant $(\mathrm{P}<0.05$; Supplementary file1: PERMANOVA). We performed Canonical Analysis of Principal coordinates (CAP) analysis for a few samples (Bulk soil-16S rRNA, bulk soil-ITS and rhizosphere-16S rRNA) not having equal variances as was clearly visible in PCoAs (Figure 2.1 and Figure 2.2). The results of CAP analyses were consistent with PERMANOVA (data not shown). There were no significant differences in microbial community composition between different blocks sampled except for fungi in bulk soil and in root endosphere compartments (Supplementary file1: PERMANOVA).

Successional stage affected the rhizosphere compartment the most and $37 \%$ and $24 \%$ of variation [(Factor sum of squares) / (total sum of squares) *100] in bacterial and fungal community composition in rhizosphere was explained by successional stage (Supplementary file1: PERMANOVA). Leaf endosphere was the least affected compartment and $16 \%$ and $10 \%$ of variation in bacterial and fungal community composition was explained by successional stage (Supplementary file1: PERMANOVA). 
Venn diagrams were used to illustrate shared bacterial and fungal OTUs in different compartments in early and late succession stages (Figure 3 and Figure 4; Supplementary file1: Shared OTUs). A substantial fraction of bacterial OTUs was shared between early and late successional stages in bulk soil (39\% shared), rhizosphere (32\% shared), leaf (28\% shared) and root endosphere (24\% shared) compartments (Figure 3). These shared OTUs represent on average $86 \%$ of total sequences in bulk soil $(85 \%)$, rhizosphere $(78 \%)$, leaf $(94 \%)$ and root endosphere $(87 \%)$ compartments.

In comparison to bacteria, fewer fungal OTUs were shared between early and late successional stages in bulk soil (19\% shared), rhizosphere (11\% shared), leaf (16\% shared) and root endosphere (14\% shared) compartments (Figure 4). These shared OTUs represent on average $48 \%$ of the total sequences in bulk soil (56\%), rhizosphere (35\%), leaf (53\%) and root endosphere $(46 \%)$ compartments.

Since the most abundant microbial OTUs were largely shared between early and late successional stages, we performed Kruskal Wallis test with log transformed $(\log [\mathrm{X}+1])$ relative abundance data to identify the OTUs that are responsible for community separation between successional stages in different compartments. To exclude rare OTUs, we included OTUs with at least $5 \%$ abundance in at least three samples, which resulted in 85 bacterial and 146 fungal OTUs. There were 71 bacterial and 62 fungal OTUs that displayed significant differences $($ FDR $<0.05)$ in their abundance across the succession in at least one compartment (Supplementary file1: Differential-OTUs abundance). The rhizosphere and bulk soil 
compartments contained the majority of the differentially abundant bacterial and fungal OTUs across the succession. The leaf endosphere compartment was least affected by succession.

\section{Higher order taxa are more affected by succession in rhizosphere than in other compartments}

We performed Kruskal Wallis test with $\log$ transformed $(\log [\mathrm{X}+1])$ relative abundance data to identify the bacterial phyla and fungal classes that differed across the succession in the different compartments. A number of bacterial phyla were differentially abundant (FDR $<0.05)$ between early and late successional stage in bulk soil (7 phyla), rhizosphere (11 phyla), and leaf (3 phyla) endosphere compartments (Supplementary file1: Differential-taxa abundance). For example, Acidobacteria were significantly $($ FDR $<0.05)$ more abundant in late than early successional stage bulk soil and rhizosphere compartments. In contrast, Actinobacteria were significantly $($ FDR $<0.05)$ more abundant in early successional stage bulk soil and rhizosphere compartments. Successional stage did not affect the relative abundance of any bacterial phylum in root endospheres.

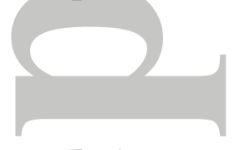

There were 22, 22, 20, and 15 different fungal classes identified in bulk soil, rhizosphere, leaf and root endosphere compartments, respectively. A few fungal classes were differently abundant $(\mathrm{FDR}<0.05)$ between early and late successional stage in bulk soil ( 3 classes $)$, rhizosphere (11 classes), and root endosphere (2 classes) compartments (Supplementary file1: Differential-taxa abundance). For example, Dothideomycetes were significantly $(\mathrm{FDR}<0.05)$ more abundant in early than late successional stage rhizosphere and root endosphere compartments. In contrast to 
bacteria, successional stage did not affect the relative abundance of higher order fungal taxa in the leaf endospheres.

\section{Co-occurring microorganisms are specific to successional stage}

To identify modules of co-occurring microorganisms (bacteria and fungi combined) within communities, we carried out co-occurrence network analyses as described by Williams et al., (2014). We identified modules containing potential co-occurring microbial communities with a correlation of 0.6 or greater within the same module (Supplementary file1: Co-occur). We found all three possible combinations of co-occurrence: bacteria-bacteria, bacteria-fungi and fungifungi (Table 2). Of the 25 modules identified, six consisted of bacterial OTUs, 16 consisted of fungal OTUs, and three contained co-occurring bacterial and fungal OTUs (Table 2).

Phylogenetically diverse bacteria and fungi were involved in the co-occurrence modules (Supplementary file1: Co-occur). For example, module number two involved different bacterial phyla such as Proteobacteria, Acidobacteria, and Actinobacteria and fungal phyla such as Ascomycota, Basidiomycota and Zygomycota. Also, we observed modules containing phylogenetically related OTUs. For example, module number 1 involved two bacterial OTUs (OTU 6 and 35) which are classified in genus Mucilaginibacter.

Most of the co-occurrence modules were specific to successional stage (Table 2). Out of the 25 co-occurrence modules identified, 17 were specific (relatively more abundant) to a successional stage. For example, module number four consisted of 12 bacterial OTUs specific to early successional stage bulk soil and rhizosphere compartments. In contrast, the module number one 
consisted of two bacterial OTUs, included generalists and occurred in all compartments in both successional stages. Of the 17 successional stage specific modules, 11 and six modules were confined to early and late successional stages, respectively.

\section{Discussion}

To our knowledge no earlier studies have comprehensively examined plant-associated bacterial and fungal communities simultaneously in the same plant species in any primary successional site. In this study, we characterized in-depth the compositions of three different plant-associated compartments, rhizosphere and endosphere (leaf and root), along with bulk soil and gained insights into the effects of succession on each of these compartments. The studied successional stages differed significantly with respect to soil physio-chemical characteristics and plant species richness.

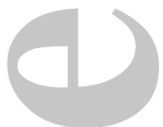

Initially, we hypothesized that microbial species richness follows plant species richness. Our results partially supported this hypothesis as microbial richness in a subset of compartments tested mirrored successional stage. In our arctic sand dune ecosystem as well as in the primary succession of glacier forefront (Brown and Jumpponen, 2014; Brown and Jumpponen, 2015), soil bacterial richness increased along succession, but soil fungal richness remained constant. Similarly, soil bacteria have been shown to follow plant succession previously in a lake sand dune succession (Williams et al., 2013). The uniformity of soil fungal richness in early and late successional stage is in contrast with the general view that organic matter quantity and especially organic matter that is difficult to decompose drives fungal species richness (Read, 1989;

Pennanen et al., 2001; van der Wal et al., 2013). Although we did not evaluate organic matter 
quality, it is logical to assume that under the late successional stage woody plant canopy and moss layer the thick organic soil layer contained more resistant organic matter than the early successional stage sandy soil under a sparse grass cover. Moss litter has been shown to resist decomposition in forest soils whereas vascular plant litter is easy to decompose (Hobbie, 1996;

Lang et al., 2009). Furthermore, amount of energy is considered one of the determinants of species richness in ecosystems (Evans et al., 2005). The early successional stage soil had very little carbon and thus energy for microbes which indicates that soil fungal species richness was not strongly determined by energy in our arctic sand dune ecosystem.

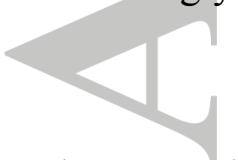

The vegetation in the early successional stage was composed of the grass Deschampsia flexuosa only whereas the late successional stage was characterized by more complex plant community. Higher plant species richness may increase microbial species richness in rhizosphere compartments (Wang et al., 2015). This effect is thought to arise through higher availability of nutrients (de Ridder-Duine et al., 2005) and increased amount and diversity of root exudates (Compant et al., 2010) in more diverse systems. In the present study, rhizosphere microbial species richness was similar across the succession suggesting that host plant species specific selection rather than bulk soil characteristics determined microbial species richness in rhizosphere.

We found that bacterial but not fungal OTU richness was higher in grass leaf endosphere in the late successional stage. These results suggest that bulk soil and leaf endophytic bacteria may follow the classic successional pathway towards increasing richness, but the richness of fungi in the same compartments may be more independent of ecosystem succession. Also, root 
endosphere fungal richness detected in this study increased along the succession. In a previous study, the root-associated (including epi- and endophytes) fungal richness increased towards the climax vegetation (Blaalid et al., 2012). A similar trend of increase in leaf bacterial and root fungal endosphere richness was observed in another independent experiment conducted two years later in the same ecosystem (Poosakkannu et al., unpublished). Our present results suggest that both bulk soil characteristics and plant selection determined endosphere microbial species richness in our ecosystem.

In this study, $73 \%$ of total bacterial endosphere OTUs and $69 \%$ of total fungal endosphere OTUs were also present in soil (Supplementary figures: Supplementary figure 2). These shared endosphere OTUs represented $96 \%$ and $94 \%$ of the total endosphere bacterial and fungal sequences. It suggests that bulk soil and rhizosphere were the main source of endosphere microbes in the present arctic sand dune ecosystem. Similarly, large proportions of wild perennial plant-associated bacteria are shared with soil in a natural ecosystem (Wagner et al., 2016).

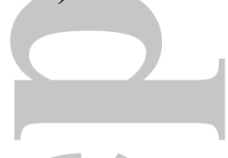

In contrast to species richness, we did get support for our initial hypothesis that succession affects microbial community composition. Succession had a significant effect on microbial communities (i.e., both bacteria and fungi) in all compartments including the leaf and root endosphere compartments. In contrast to our work, bacterial root endosphere species composition remained unaffected by succession in salt marsh chronosequence (Wang et al., 2015). At present, the progressive succession in our experimental ecosystem is extremely slow and mainly degradation from later successional stages towards earlier one is taking place. This is 
because the area is intensively grazed by reindeer and aeolian activity causes disturbance beyond the carrying capacity of the ecosystem. In salt marsh chronosequence succession is progressive i.e., early to late successional stage formation (Wang et al., 2015). These differences along with the different span of chronosequence and the plant species studied are potential reasons for the difference in endosphere species composition observed between the two studies. Further studies on successional trajectory of endosphere microbial communities in different systems will reveal whether the endosphere microbial community is idiosyncratic or whether general patterns emerge.

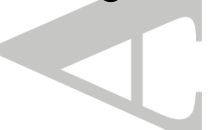

In our work, relative abundance of different microbial taxa (at phyla/class/OTU level) in rhizosphere was the most affected by successional stage followed by bulk soil. A total of $50 \%$ or more bacterial and fungal taxa were differentially abundant in rhizosphere compartment between early and late successional stage. These dominant taxa possibly have a specific role in succession. For example, Actinobacteria are known to be successful under nutrient poor conditions (Dion and Nautiyal, 2008). Some of them are able to fix atmospheric nitrogen, which could explain their prevalence in the present study in the rhizosphere compartments in the early successional stage with low plant cover. Late successional stage soils in our system had clearly higher organic matter content and lower soil $\mathrm{pH}$ in comparison to the early successional stage, which could explain increased relative abundance of Acidobacteria. It is known that Acidobacteria dominate acidic, high organic matter content soils in arctic tundra and correlate negatively,with pH (Jones et al., 2009; Männistö et al., 2013).

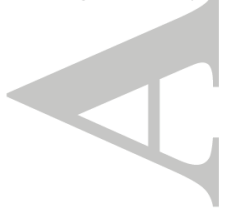


The direct and indirect interactions between microbial taxa coexisting in plant and soil habitats have rarely been studied. We applied network analysis to explore the co-occurrence of bacterial and fungal taxa in plant endosphere and in the associated soil samples. Diverse taxa were involved in co-occurrence networks and most of the co-occurrence patterns were specific to successional stage supporting our initial hypothesis. A total of $68 \%$ of the potential co-occurring modules were successional stage specific. Of the $68 \%$ of successional stage specific modules, 65 $\%$ were specific to early successional stage, which stresses the importance of co-occurrence in nutrient poor early successional stage. In this study, some of the co-occurrence modules consisted of phylogenetically close OTUs indicating that closely related organisms could share similar ecology as shown by Cardinale et al., (2015). The limited taxonomic information at the lowest taxonomic level makes it difficult to infer the functional relevance of intra or interkingdom co-occurrence patterns observed in this study. However, recognition of co-occurrence patterns is an important step in identifying microbial species interactions in microbial community dynamics and function (Schlatter et al., 2015).

In conclusion, successional trajectories of plant-associated microbes are compartment-dependent and bacteria and fungi do not follow similar successional trajectories. Further comparisons of bacterial and fungal trajectories in different ecosystems and plant species (including different compartments) are needed to fully understand the successional differences between plantassociated prokaryotic and eukaryotic microbes.

\section{Experimental procedures}

\section{Study site}


The present study site is located in an inland aeolian sand dune area in Northern Fennoscandia $\left(68^{\circ} 29^{\prime} 16^{\prime \prime} \mathrm{N}, 24^{\circ} 42^{\prime} 13^{\prime \prime} \mathrm{E}\right)$. During and after ice age, glacial retreat and wind resulted in inland sand dunes that are today mostly covered by vegetation. Occasionally, the ecosystem has eroded to such an extent that large areas are devoid of vegetation. Loss of plant cover and resulting sand drifting has been occurring at least for the last 700 years (Seppälä, 1995). As a consequence, the present plant cover consists of a mosaic of different successional stages.

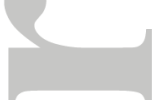

In this study, we focused on an early and a late successional stage. The early successional stage is characterized by the presence of only one plant species, the grass Deschampsia flexuosa and most of the soil surface is exposed sand (here after referred to as "early"). Late successional stage is characterized by the presence of 10 different plant species which includes sparse mountain birch (Betula pubescens ssp. czerepanovii) and continuous ground cover composed of Deschampsia flexuosa together with Empetrum nigrum and the moss Pleurozium schreberi (here after referred to as "late").

The physio-chemical properties of the two successional stages are listed in Supplementary file1:

Soil_properties. The 1981-2000 average annual temperature in the region was $-1.3{ }^{\circ} \mathrm{C}$, with extreme temperatures between $-51.5^{\circ} \mathrm{C}$ to $+30.2^{\circ} \mathrm{C}$ (Pirinen et al. 2012).

\section{Collection of soil and plant materials}

We collected a total of 96 samples comprised of four different compartments: Bulk soil, rhizosphere soil, Deschampsia flexuosa leaf and root samples. Each of these compartment samples comprised of 24 replicates, i.e., 12 replicates per each successional stage. Successional 
stage samples were collected in four blocks, i.e., 3 replicates per block per successional stage per compartment.

The sampling was conducted in 24th July 2011. Plants were carefully dug out with an intact root system. The loose soil was removed by gently shaking the roots. The rhizosphere soil tightly adhering to the roots was collected by vigorously shaking the roots on top of a sheet of tin foil. After that the roots were thoroughly washed and leaves and roots were separated from the rhizome. The surface sterilization of leaves and roots was carried out as described in Poosakkannu et al., (2015). One sample of rhizosphere soil, leaf and root each was collected from each individual plant. The bulk soil samples were taken within 3 meters distance of the focal plant. Each bulk soil samples are composite samples of 5 cups each c. $100 \mathrm{~cm}^{3}$ in volume. Bulk soil samples were processed to remove any plant material. The rooting depth of plants depends on the successional stage (approximately 2-20 $\mathrm{cm}$ for late and 7-50 $\mathrm{cm}$ for early successional stage). Therefore we harvested the soil (bulk soil and rhizosphere) profile that is common to both successional stages at $10-20 \mathrm{~cm}$.

\section{DNA extraction, PCR and sequencing}

Microbial DNA was extracted from ca $0.5 \mathrm{~g}$ of bulk and $0.3 \mathrm{~g}$ of rhizosphere soil using the PowerSoil DNA isolation kit (MoBio, Carlsbad, CA, USA) following manufacturer's instructions. DNA from plant samples was isolated from $1 \mathrm{~g}$ of root or leaf tissues using Qiagen DNeasy Plant Maxi Kit following manufacturer's instructions. 
For $16 \mathrm{~S}$ rRNA region amplification, we used nested approach. Briefly, first round of PCR was performed with 799f/ 1492R primer pairs which resulted in differential size amplification of mitochondrial DNA and bacterial DNA and excludes plastid DNA amplification (Chelius and Triplett 2001). The second round of PCR was performed with 1062F/1390R primer pairs.

For ITS region amplification, we used fITS7/ITS4 primer pairs to overcome strong bias against species with longer amplicons when using ITS1F and ITS4R primer combination (Ihrmark et al., 2012).

PCR reactions were performed in duplicate for each experimental unit to minimize PCR biases. We used M13 system for library preparation as described by Mäki et al., (2016). Prior to sequencing, the 16S rRNA gene amplicons were size fractionated (Pippin Prep, Sage Science) to eliminate the mitochondrial amplicons. For primers used, PCR and library preparation details, see supplementary file 1:M13-primers and supplementary file 2. The sequencing was carried out using the Ion PGM Sequencing 400 Kit (Ion 314 chips; Life Technologies, Thermo Fisher Scientific, Waltham, Massachusetts, USA) following the manufacturer's instructions.

\section{Bioinformatics}

The bacterial 16S rRNA and fungal ITS sequences were reassigned to their respective samples and quality filtered using the Mothur v.1.35.0 (parameters: minlength $=200$; maxambigs $=0$; maxhomop $=8 ;$ qwindowaverage $=25 ;$ qwindowsize $=50 ;$ and bdiffs $=1$ ).

Further processing of bacterial 16S rRNA gene sequences in Mothur was performed following a standard procedure (Schloss et al., 2011). Briefly, the bacterial 16S rRNA sequences were 
aligned and chimeras checked using SILVA based reference database

(http://www.mothur.org/wiki/Silva_reference_files). The sequences were further clustered at 97\% sequence similarity thresholds and classified using ribosomal database project (RDP) database (http://www.mothur.org/wiki/RDP reference files).

Fungal ITS sequences were processed as described in Tedersoo et al., (2014). Briefly, ITSx 1.0.7 software (http://microbiology.se/software/itsx) was used to remove the flanking $5.8 S$ and $28 S$ rRNA regions of ITS sequences which ensure optimal resolution of ITS clustering and removal of non-target sequences. All the potential chimeric reads were identified and removed through Mothur embedded UCHIME 4.2 software (http://drive5.com/uchime). The quality filtered ITS sequences were clustered at $97 \%$ sequence similarity thresholds as implemented in CD-HIT 4.6.1 (cd-hit.org). Identities were assigned to the sequences using the UNITE+INSD datasets (http://www.mothur.org/wiki/UNITE_ITS_database).

All the OTUs with five or less than five sequences across the samples were excluded from downstream analyses. For downstream analyses, all of the bacterial and fungal sequence samples were rarefied to the minimum sequencing depth (Bacteria-1,701; Fungi-1,304) and used to generate OTU abundance table. The raw sequence data are available in National Center for Biotechnology Information Sequence Read Archive under accession number SRP063711. The observed species richness, estimated species richness (Chao 1) and Shannon diversity indices were estimated in Mothur v.1.35.0.

\section{Statistical analyses}


To visualize shifts in the microbial community composition, principal coordinate analysis (PCoA) based on Bray-Curtis dissimilarities was used. We performed PERMDISP (Anderson, 2001) analysis to ascertain variance homogeneity across samples. The effect of successional stages on microbial community composition was tested using a Permutational Multivariate Analysis of Variance (PERMANOVA; Anderson, 2001). PERMANOVA was carried out using successional stage as a fixed factor and block as a random factor. All of the above statistical analyses were performed in PRIMER software v6 (Clark and Warwick, 2001).

\section{Co-occurrence network analysis}

Bacterial dataset was rarefied to the fungal sequence depth per sample (1304) before combining both bacterial and fungal OTU abundance data for further analysis. Further, we have included only the OTUs with 5\% abundance in at least three samples. Spearman's Pairwise correlations were calculated using the script named co_occurrence_pairwise_routine.R (Williams et al., 2014). We only considered positive and negative co-occurrence relationships based on strength of correlation (i.e., $\rho$ from the Spearman's correlation) at values greater than or equal to 0.6 and less than or equal to -0.6. Based on the Spearman's Pairwise correlations co-occurred microbes were allocated to their respective modules using comm_stat_function.R (Williams et al., 2014). Modules were allocated to successional stages or compartment based on relative abundances of modules OTU reads in different successional stage/compartment. The co-occurrence analysis was performed using R statistical software v.3.2.1.

\section{Acknowledgement}


The authors wish to thank funding from Maj and Tor Nessling foundation (grant \# 201300249), Centre for International Mobility, Oskar Öflunds Stiftelse and Department of Biological and Environmental Science, University of Jyväskylä and Academy of Finland (grant \# 259180, \#287545). We thank Manoj Kumar and Helena Jauhiainen for their great help during the field work, Prof. Marja Tiirola and MSc Anita Mäki for their valuable help and guidance in Ion Torrent sequencing stream and Dr. Heli Juottonen for helping with various aspects of the work.

\section{Conflict of interest}

The authors declare no conflict of interest.

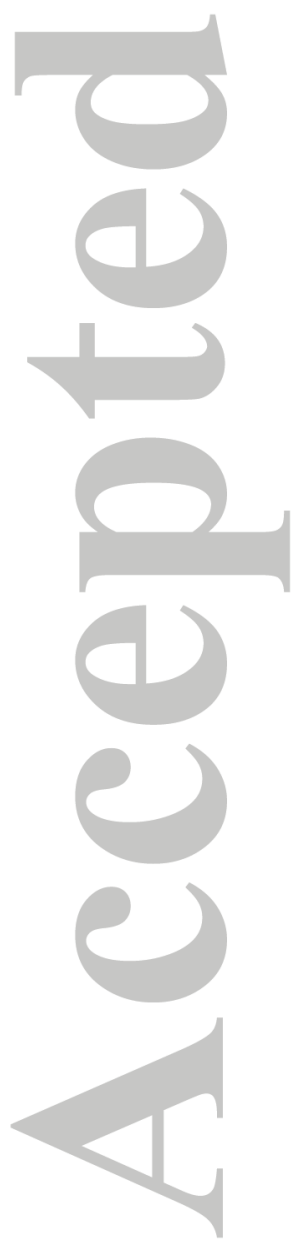




\section{References}

Anderson, M. J. (2005) Permutational multivariate analysis of variance. Department of Statistics, University of Auckland, Auckland 26: 32-46.

Barberán, A., Bates, S. T., Casamayor, E. O., \& Fierer, N. (2012) Using network analysis to explore co-occurrence patterns in soil microbial communities. ISME J 6: 343-351.

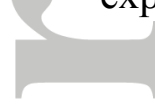

Bardgett, R. D., \& Chan, K. F. (1999) Experimental evidence that soil fauna enhance nutrient mineralization and plant nutrient uptake in montane grassland ecosystems. Soil Biol Biochem 31: 1007-1014.

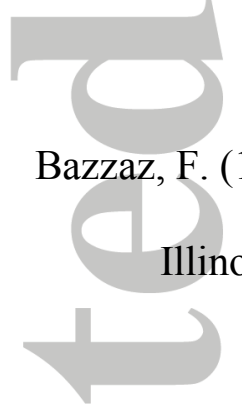

Belnap, J., \& Lange, O. (2003) Biological Soil Crust: Structure, Function, and Management.

Berendse, F., Lammerts, E., \& Olff, H. (1998) Soil organic matter accumulation and its implications for nitrogen mineralization and plant species composition during succession in coastal dune slacks. Plant Ecol 137: 71-78.

Berg, G., Grube, M., Schloter, M., \& Smalla, K. (2014) The plant microbiome and its importance for plant and human health. Frontiers in microbiology 5: 1. 
Berg, G., \& Smalla, K. (2009) Plant species and soil type cooperatively shape the structure and function of microbial communities in the rhizosphere. FEMS Microbiol Ecol 68: 1-13.

Bertness, M. D., \& Callaway, R. (1994) Positive interactions in communities. Trends in Ecology \& Evolution 9: 191-193.

Blaalid, R., Carlsen, T., Kumar, S., Halvorsen, R., Ugland, K. I., Fontana, G., \& Kauserud, H. (2012) Changes in the root-associated fungal communities along a primary succession gradient analysed by 454 pyrosequencing. Mol Ecol 21: 1897-1908.

Brooker, R. W., \& Callaghan, T. V. (1998) The balance between positive and negative plant interactions and its relationship to environmental gradients: a model. Oikos 196-207.

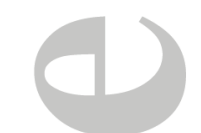

Brown, S. P., \& Jumpponen, A. (2015) Phylogenetic diversity analyses reveal disparity between fungal and bacterial communities during microbial primary succession. Soil Biol Biochem 89: 52-60.

Brown, S. P., \& Jumpponen, A. (2014) Contrasting primary successional trajectories of fungi and bacteria in retreating glacier soils. Mol Ecol 23: 481-497.

Bulgarelli, D., Garrido-Oter, R., Münch, P. C., Weiman, A., Dröge, J., Pan, Y. et al. (2015) Structure and Function of the Bacterial Root Microbiota in Wild and Domesticated Barley. Cell host \& microbe 17: 392-403. 
Bulgarelli, D., Rott, M., Schlaeppi, K., van Themaat, Emiel Ver Loren, Ahmadinejad, N., Assenza, F. et al. (2012) Revealing structure and assembly cues for Arabidopsis rootinhabiting bacterial microbiota. Nature 488: 91-95.

Cardinale, M., Grube, M., Erlacher, A., Quehenberger, J., \& Berg, G. (2015) Bacterial networks and co-occurrence relationships in the lettuce root microbiota. Environ Microbiol 17:

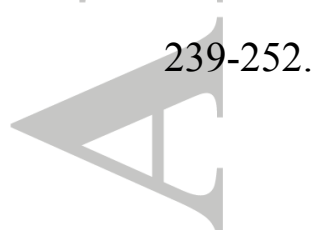

Chapin, F. S., Walker, L. R., Fastie, C. L., \& Sharman, L. C. (1994) Mechanisms of primary succession following deglaciation at Glacier Bay, Alaska. Ecol Monogr 64: 149-175.

Chelius, M., \& Triplett, E. (2001) The Diversity of Archaea and Bacteria in Association with the Roots of Zea mays L. Microb Ecol 41: 252-263.

Clarke, K., \& Warwick, R. (2001) Change in Marine Communities: An Approach to Statistical Analysis and Interpretation (PRIMER-E). Plymouth Marine Laboratory, Plymouth, UK.,

Coleman-Derr, D., Desgarennes, D., Fonseca-Garcia, C., Gross, S., Clingenpeel, S., Woyke, T. et al. (2016) Plant compartment and biogeography affect microbiome composition in cultivated and native Agave species. New Phytol 209: 798-811. 
Compant, S., Clément, C., \& Sessitsch, A. (2010) Plant growth-promoting bacteria in the rhizoand endosphere of plants: their role, colonization, mechanisms involved and prospects for utilization. Soil Biol Biochem 42: 669-678.

Cowles, H. C. (1899) The Ecological Relations of the Vegetation on the Sand Dunes of Lake Michigan. Part I.-Geographical Relations of the Dune Floras. Botanical Gazette 27: 95117.

de Ridder-Duine, A. S., Kowalchuk, G. A., Gunnewiek, P. J. K., Smant, W., van Veen, J. A., \& de Boer, W. (2005) Rhizosphere bacterial community composition in natural stands of Carex arenaria (sand sedge) is determined by bulk soil community composition. Soil Biol Biochem 37: 349-357.

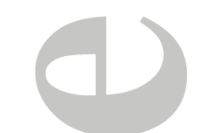

Diaz, S., Grime, J., Harris, J., \& McPherson, E. (1993) Evidence of a feedback mechanism limiting plant response to elevated carbon dioxide. Nature 364: 616-617.

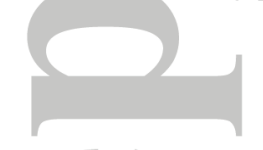

Dion, P., \& Nautiyal, C. (2008) Extreme views on prokaryote evolution. In - Microbiology of extreme soils. P. Dion, \& C. Nautiyal (eds). Microbiology of Extreme Soils (eds DionP, NautiyalCS) edn. Berlin Heidelberg, - Springer, pp. 45-70.

Edwards, J., Johnson, C., Santos-Medellin, C., Lurie, E., Podishetty, N. K., Bhatnagar, S. et al. (2015) Structure, variation, and assembly of the root-associated microbiomes of rice.

Proc Natl Acad Sci U S A 112: E911-20. 
Evans, K. L., Greenwood, J. J., \& Gaston, K. J. (2005) Dissecting the species-energy relationship. Proc Biol Sci 272: 2155-2163.

Frey-Klett, P., Burlinson, P., Deveau, A., Barret, M., Tarkka, M., \& Sarniguet, A. (2011)

Bacterial-fungal interactions: hyphens between agricultural, clinical, environmental, and food microbiologists. Microbiol Mol Biol Rev 75: 583-609.

Gottel, N. R., Castro, H. F., Kerley, M., Yang, Z., Pelletier, D. A., Podar, M. et al. (2011)

Distinct microbial communities within the endosphere and rhizosphere of Populus deltoides roots across contrasting soil types. Appl Environ Microbiol 77: 5934-5944.

Hardoim, P. R., Hardoim, C. C., Van Overbeek, L. S., \& Van Elsas, J. D. (2012) Dynamics of seed-borne rice endophytes on early plant growth stages. PLoS One 7: e30438.

Hobbie, S. E. (1996) Temperature and plant species control over litter decomposition in Alaskan tundra. Ecol Monogr 66: 503-522.

Ihrmark, K., Bodeker, I. T., Cruz-Martinez, K., Friberg, H., Kubartova, A., Schenck, J. et al. (2012) New primers to amplify the fungal ITS2 region--evaluation by 454-sequencing of artificial and natural communities. FEMS Microbiol Ecol 82: 666-677. 
Johnston-Monje, D., \& Raizada, M. N. (2011) Conservation and diversity of seed associated endophytes in Zea across boundaries of evolution, ethnography and ecology. PLoS One 6: e20396.

Johnston-Monje, D., Mousa, W. K., Lazarovits, G., \& Raizada, M. N. (2014) Impact of swapping soils on the endophytic bacterial communities of pre-domesticated, ancient and modern maize. BMC plant biology 14: 1.

Jones, R. T., Robeson, M. S., Lauber, C. L., Hamady, M., Knight, R., \& Fierer, N. (2009) A comprehensive survey of soil acidobacterial diversity using pyrosequencing and clone library analyses. ISME J 3: 442-453.

\section{$(-3)$}

Kumari, B. (2016) Phosphate solubilizing microbes: an effective and alternative approach as biofertilizers. International Journal of Pharmacy and Pharmaceutical Sciences 8: 37-40.

Lang, S. I., Cornelissen, J. H., Klahn, T., Van Logtestijn, R. S., Broekman, R., Schweikert, W., \& Aerts, R. (2009) An experimental comparison of chemical traits and litter decomposition rates in a diverse range of subarctic bryophyte, lichen and vascular plant species. J Ecol 97: 886-900.

Long, H. H., Schmidt, D. D., \& Baldwin, I. T. (2008) Native bacterial endophytes promote host growth in a species-specific manner; phytohormone manipulations do not result in common growth responses. PLoS One 3: e2702. 
Lundberg, D. S., Lebeis, S. L., Paredes, S. H., Yourstone, S., Gehring, J., Malfatti, S. et al. (2012) Defining the core Arabidopsis thaliana root microbiome. Nature 488: 86-90.

Mäki, A., Rissanen, A. J., \& Tiirola, M. (2016) A practical method for barcoding and sizetrimming PCR templates for amplicon sequencing. BioTechniques 60: 88-90.

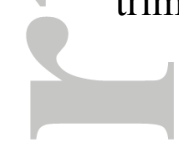

Männistö, M. K., Kurhela, E., Tiirola, M., \& Haggblom, M. M. (2013) Acidobacteria dominate the active bacterial communities of Arctic tundra with widely divergent winter-time snow accumulation and soil temperatures. FEMS Microbiol Ecol 84: 47-59.

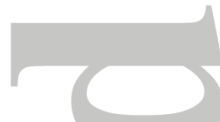

Nemergut, D. R., Anderson, S. P., Cleveland, C. C., Martin, A. P., Miller, A. E., Seimon, A., \& Schmidt, S. K. (2007) Microbial community succession in an unvegetated, recently deglaciated soil. Microb Ecol 53: 110-122.

Normander, B., \& Prosser, J. I. (2000) Bacterial origin and community composition in the barley phytosphere as a function of habitat and presowing conditions. Appl Environ Microbiol 66: $4372-4377$.

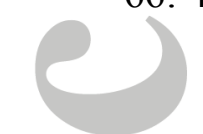

Peiffer, J. A., Spor, A., Koren, O., Jin, Z., Tringe, S. G., Dangl, J. L. et al. (2013) Diversity and heritability of the maize rhizosphere microbiome under field conditions. Proc Natl Acad Sci U S A 110: 6548-6553. 
Pennanen, T., Strömmer, R., Markkola, A., \& Fritze, H. (2001) Microbial and plant community structure across a primary succession gradient. Scand J For Res 16: 37-43.

Philippot, L., Raaijmakers, J. M., Lemanceau, P., \& van der Putten, Wim H. (2013) Going back to the roots: the microbial ecology of the rhizosphere. Nature Reviews Microbiology 11: 789-799.

Pirinen, P., Simola, H., Aalto, J., Kaukoranta, J., Karlsson, P., \& Ruuhela, R. (2012)

Climatological statistics of Finland 1981-2010. Finnish Meteorological Institute Reports 1: $1-96$.

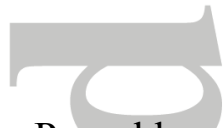

Poosakkannu, A., Nissinen, R., \& Kytöviita, M. (2015) Culturable endophytic microbial communities in the circumpolar grass, Deschampsia flexuosa in a sub-Arctic inland primary succession are habitat and growth stage specific. Environmental Microbiology Reports 7: 111-122.

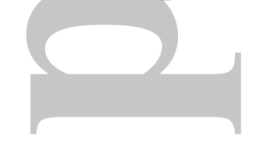

Puente, M. E., Li, C. Y., \& Bashan, Y. (2009) Endophytic bacteria in cacti seeds can improve the development of cactus seedlings. Environ Exp Bot 66: 402-408.

Read, D. (1989) Mycorrhizas and nutrient cycling in sand dune ecosystems. Proceedings of the Royal Society of Edinburgh Section B Biological Sciences 96: 80-110. 
Schlatter, D. C., Bakker, M. G., Bradeen, J. M., \& Kinkel, L. L. (2015) Plant community richness and microbial interactions structure bacterial communities in soil. Ecology 96: 134-142.

Schloss, P. D., Gevers, D., \& Westcott, S. L. (2011) Reducing the effects of PCR amplification and sequencing artifacts on 16S rRNA-based studies. PLoS One 6: e27310.

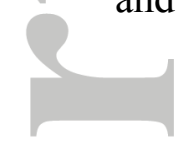

Seppälä, M. (1995) Deflation and redeposition of sand dunes in Finnish Lapland. Quaternary Science Reviews 14: 799-809.

Singh, B. K., Munro, S., Potts, J. M., \& Millard, P. (2007) Influence of grass species and soil type on rhizosphere microbial community structure in grassland soils. Applied Soil Ecology 36: 147-155.

Tedersoo, L., Bahram, M., Polme, S., Koljalg, U., Yorou, N. S., Wijesundera, R. et al. (2014) Fungal biogeography. Global diversity and geography of soil fungi. Science 346: 1256688.

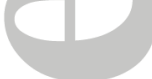

Tews, J., Brose, U., Grimm, V., Tielbörger, K., Wichmann, M., Schwager, M., \& Jeltsch, F. (2004) Animal species diversity driven by habitat heterogeneity/diversity: the importance of keystone structures. J Biogeogr 31: 79-92. 
van der Wal, A., Geydan, T. D., Kuyper, T. W., \& de Boer, W. (2013) A thready affair: linking fungal diversity and community dynamics to terrestrial decomposition processes. FEMS Microbiol Rev 37: 477-494.Walker, L. R., \& Del Moral, R. (2003) Primary succession and ecosystem rehabilitation. Cambridge University Press,

Wang, M., Yang, P., \& Salles, J. F. (2015) Distribution of root-associated bacterial communities along a salt-marsh primary succession. Frontiers in plant science 6: 1-11.

Williams, M. A., Jangid, K., Shanmugam, S. G., \& Whitman, W. B. (2013) Bacterial communities in soil mimic patterns of vegetative succession and ecosystem climax but are resilient to change between seasons. Soil Biol Biochem 57: 749-757.

Williams, R. J., Howe, A., \& Hofmockel, K. S. (2014) Demonstrating microbial co-occurrence pattern analyses within and between ecosystems. Frontiers in microbiology 5: 1-10.

Wilson, P. W. (1940) The biochemistry of symbiotic nitrogen fixation. The biochemistry of symbiotic nitrogen fixation 22: 121-140.

Yang, J., Kloepper, J. W., \& Ryu, C. (2009) Rhizosphere bacteria help plants tolerate abiotic stress. Trends Plant Sci 14: 1-4.

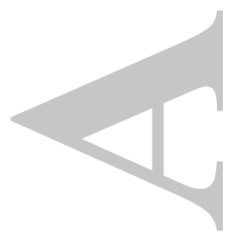


Zelezniak, A., Andrejev, S., Ponomarova, O., Mende, D. R., Bork, P., \& Patil, K. R. (2015) Metabolic dependencies drive species co-occurrence in diverse microbial communities.

Proc Natl Acad Sci U S A 112: 6449-6454.
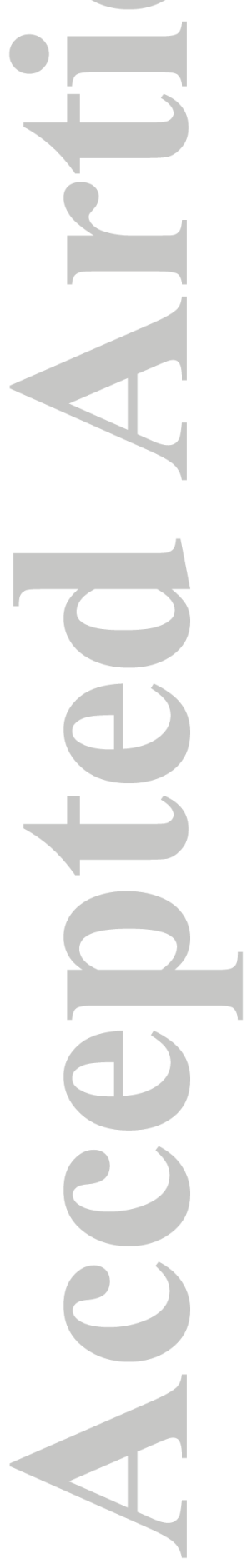


\begin{tabular}{|c|c|c|c|c|c|c|}
\hline Taxa & $\begin{array}{l}\text { Diversity } \\
\text { indices }\end{array}$ & $\begin{array}{l}\text { Succes } \\
\text {-sional } \\
\text { stage }\end{array}$ & $\begin{array}{l}\text { Bulk soil } \\
\text { (mean } \pm \\
\text { SE) }\end{array}$ & $\begin{array}{l}\text { Rhizosphere } \\
(\text { mean } \pm \text { SE) }\end{array}$ & $\begin{array}{l}\text { Leaf } \\
\text { endosphere } \\
(\text { mean } \pm \mathrm{SE})\end{array}$ & $\begin{array}{l}\text { Root } \\
\text { endosphere } \\
(\text { mean } \pm \text { SE) }\end{array}$ \\
\hline \multirow[t]{6}{*}{ Bacteria } & $\begin{array}{l}\text { Observed } \\
\text { OTU }\end{array}$ & Early & $\begin{array}{l}251.67 \pm \\
34.5\end{array}$ & $\begin{array}{l}322.75 \pm \\
14.46\end{array}$ & $58.92 \pm 3.99$ & $99.08 \pm 7.70$ \\
\hline & richness & Late & $\begin{array}{l}388.50 \pm \\
10.69\end{array}$ & $\begin{array}{l}379.08 \pm \\
15.23\end{array}$ & $88.83 \pm 6.66$ & $\begin{array}{l}117.42 \pm \\
16.78\end{array}$ \\
\hline & $\begin{array}{l}\text { Estimated } \\
\text { OTU }\end{array}$ & Early & $\begin{array}{l}377.02 \pm \\
56.12\end{array}$ & $\begin{array}{l}563.38 \pm \\
30.45\end{array}$ & $\begin{array}{l}100.89 \pm \\
7.83\end{array}$ & $\begin{array}{l}136.48 \pm \\
12.99\end{array}$ \\
\hline & richness & Late & $\begin{array}{l}702.12 \pm \\
42.34\end{array}$ & $\begin{array}{l}703.34 \pm \\
37.13\end{array}$ & $\begin{array}{l}154.94 \pm \\
17.15\end{array}$ & $\begin{array}{l}210.45 \pm \\
34.68\end{array}$ \\
\hline & Shannon & Early & $4.07 \pm 0.38$ & $4.53 \pm 0.12$ & $1.46 \pm 0.10$ & $2.82 \pm 0.18$ \\
\hline & $\begin{array}{l}\text { diversity } \\
\text { index }\end{array}$ & Late & $4.90 \pm 0.03$ & $4.78 \pm 0.09$ & $2.21 \pm 0.23$ & $2.48 \pm 0.20$ \\
\hline \multirow[t]{5}{*}{ Fungi } & $\begin{array}{l}\text { Observed } \\
\text { OTU }\end{array}$ & Early & $\begin{array}{l}122.33 \pm \\
10.48\end{array}$ & $\begin{array}{l}154.25 \pm \\
11.07\end{array}$ & $62.83 \pm 3.40$ & $79.33 \pm 5.51$ \\
\hline & richness & Late & $\begin{array}{l}161.42 \pm \\
6.01\end{array}$ & $\begin{array}{l}165.50 \pm \\
10.29\end{array}$ & $55.83 \pm 4.57$ & $96.17 \pm 5.46$ \\
\hline & $\begin{array}{l}\text { Estimated } \\
\text { OTU }\end{array}$ & Early & $\begin{array}{l}217.62 \pm \\
27.06\end{array}$ & $\begin{array}{l}254.27 \pm \\
17.66\end{array}$ & $\begin{array}{l}100.35 \pm \\
12.20\end{array}$ & $\begin{array}{l}127.29 \pm \\
10.36\end{array}$ \\
\hline & richness & Late & $\begin{array}{l}278.56 \pm \\
16.80\end{array}$ & $\begin{array}{l}292.19 \pm \\
14.99\end{array}$ & $89.54 \pm 7.58$ & $\begin{array}{l}152.97 \pm \\
9.52\end{array}$ \\
\hline & Shannon & Early & $3.18 \pm 0.18$ & $3.47 \pm 0.14$ & $2.03 \pm 0.12$ & $2.41 \pm 0.16$ \\
\hline
\end{tabular}




\begin{tabular}{|l|l|l|l|l|l|l|}
\hline diversity & Late & $3.62 \pm 0.11$ & $3.54 \pm 0.14$ & $1.96 \pm 0.15$ & $2.46 \pm 0.16$ \\
index & & & & & \\
\hline
\end{tabular}

Table 1. Observed OTU richness (mean $\pm \mathrm{SE})$, estimated OTU richness (mean $\pm \mathrm{SE}$ ) and shannon-wiener diversity index (mean \pm SE) of 16S rRNA bacterial OTUs and ITS fungal OTUs in bulk soil, rhizosphere, Deschampsia flexuosa leaf and root endosphere in early and late successional stages. OTUs were clustered at 97\% similarity level. Statistically significant $(\mathrm{P}<0.05)$ differences are shown in bold letters.

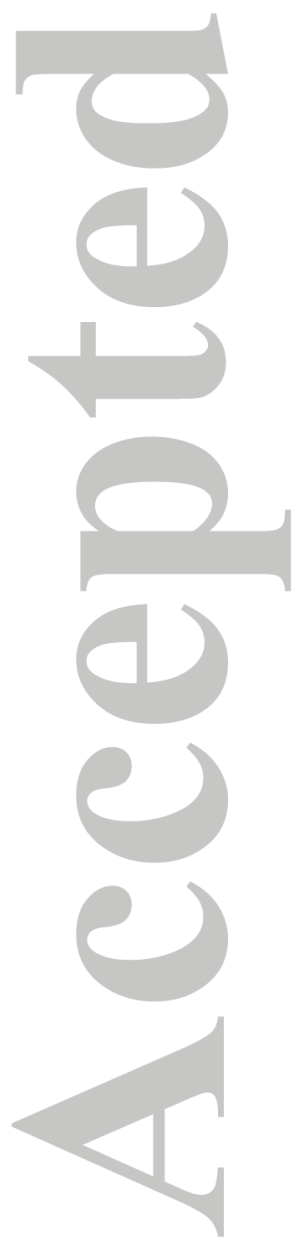




\begin{tabular}{|l|l|l|l|}
\hline Successional stage (Compartments) & Module & No. Of & Co-occurrence \\
(no & OTUs
\end{tabular}




\begin{tabular}{|l|l|l|l|}
\hline Late (Root) & 22 & 5 & Fungi-fungi \\
\hline Generalist (Root) & 23 & 2 & Fungi-fungi \\
\hline Early (Rhizosphere and root) & 24 & 2 & Fungi-fungi \\
\hline Generalist (Bulk soil, rhizosphere and & 25 & 2 & Fungi-fungi \\
root) & & & \\
\hline
\end{tabular}

Table 2. Number of co-occuring modules and number of OTUs in every module with their cooccurrence type and successional stage specificity.

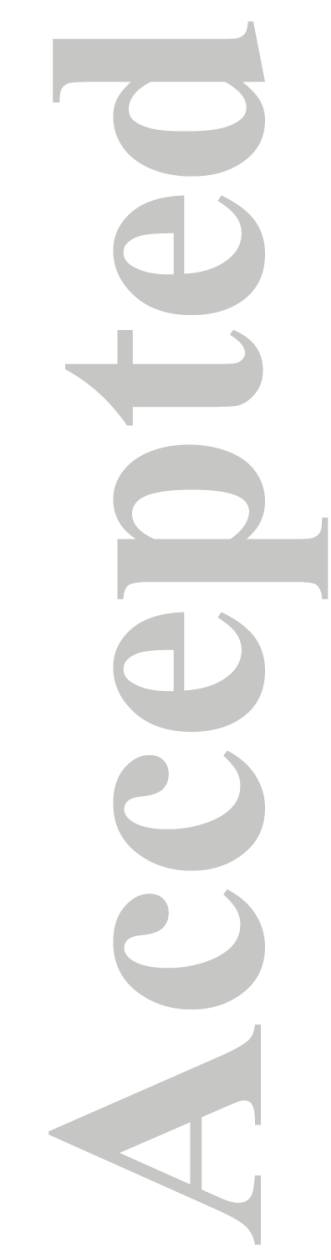




\section{Figure legends}

Figure 1. Map of the geographic location of the sampling sites in Northern Fennoscandia $\left(68^{\circ}\right.$ $29^{\prime} 16^{\prime \prime} \mathrm{N}, 24^{\circ} 42^{\prime} 13^{\prime \prime}$ E), Finland. The numbers (1, 2, 3 and 4) represent different blocks. The detailed view represents the " 1 st block" and sampling scheme. The location of the blocks was defined by the scarcity of the late successional stage vegetation. Figure contains data from the National Land Survey of Finland Topographic Database 10/2015.

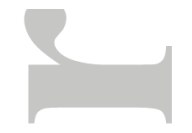

Figure 2.1 and 2.2. Clustering pattern of bacterial (2.1) and fungal (2.2) community composition in bulk soil, rhizosphere, Deschampsia flexuosa leaf and root endosphere in the early and late successional stage. OTUs were clustered at 97\% similarity level. The weighted and constrained principal-coordinate analysis (PCoA) based on Bray-Curtis dissimilarity on standardized and square-root transformed data was performed in PRIMER software v6.

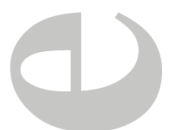

Figure 3. Venn diagram showing the number of shared and unique bacterial 16S rRNA OTUs in (A) bulk soil, (B) rhizosphere, (C) Deschampsia flexuosa leaf and (D) Deschampsia flexuosa root endosphere in the early and late successional stage. OTUs were clustered at $97 \%$ similarity level. Venn diagrams were generated in Mothur v.1.35.0 and modified using Venn diagram plotter software.

Figure 4. Venn diagram showing the number of shared and unique fungal ITS OTUs in (A) bulk soil, (B) rhizosphere, (C) Deschampsia flexuosa leaf and (D) Deschampsia flexuosa root endosphere in the early and late successional stage. OTUs were clustered at 97\% similarity level. 
Venn diagrams were generated in Mothur v.1.35.0 and modified using Venn diagram plotter software.
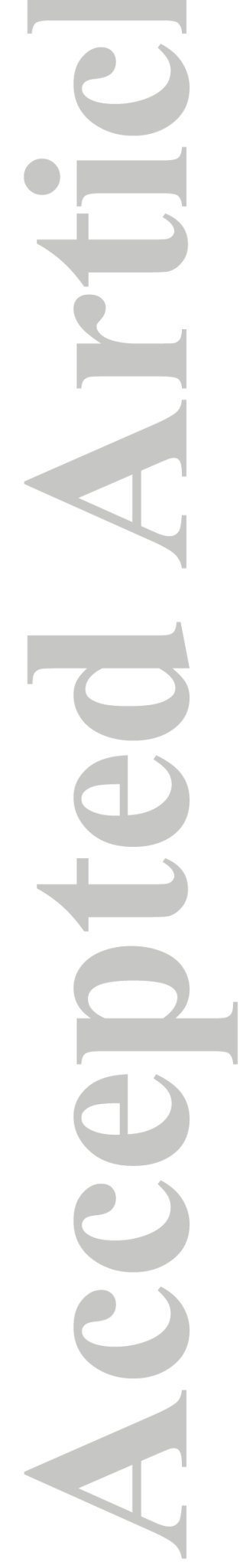

\begin{tabular}{l|l} 
Page & 38
\end{tabular}

Wiley-Blackwell and Society for Applied Microbiology

This article is protected by copyright. All rights reserved. 


\section{Page 39 of 43}
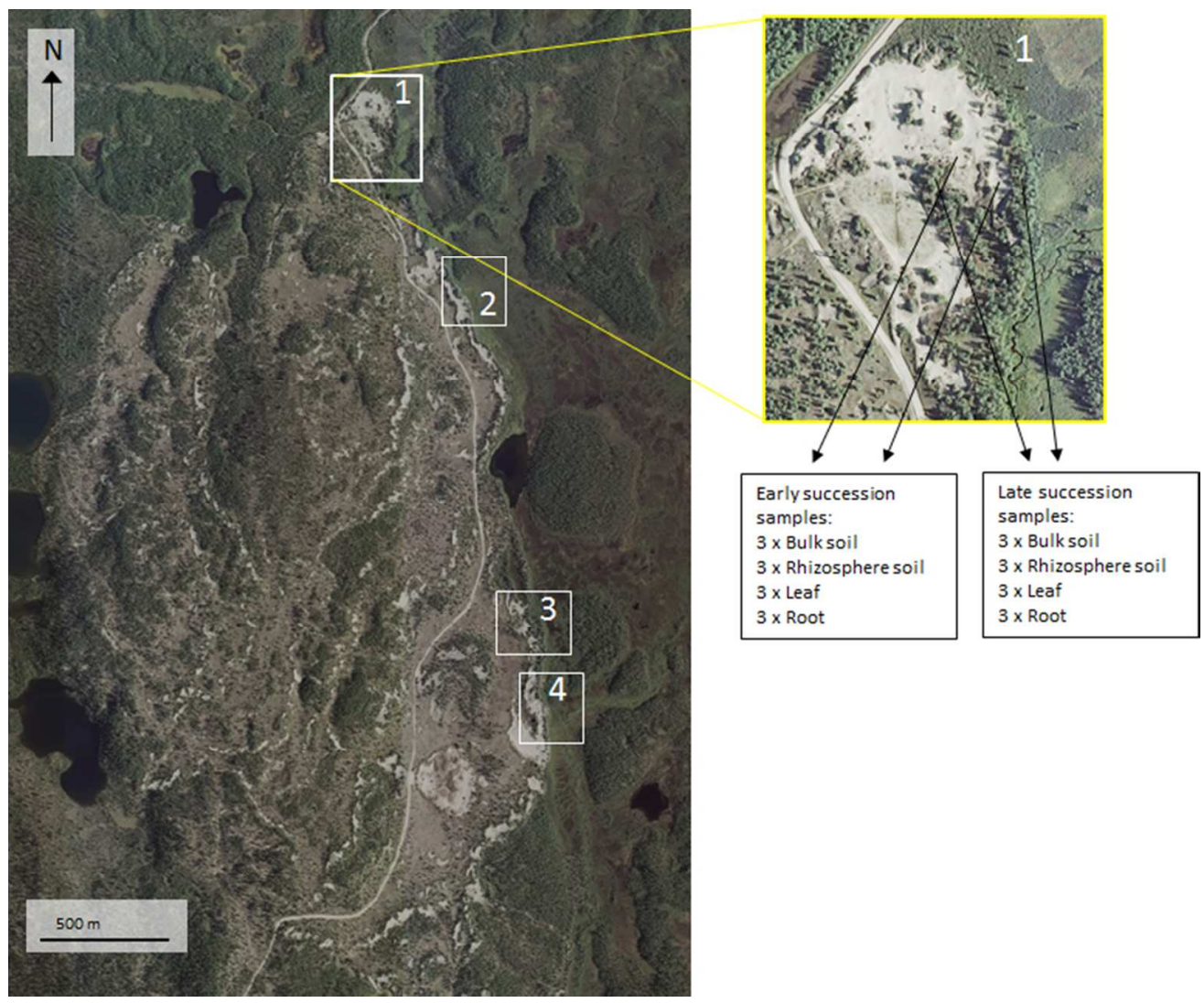

Figure 1

$203 \times 168 \mathrm{~mm}(96 \times 96 \mathrm{DPI})$

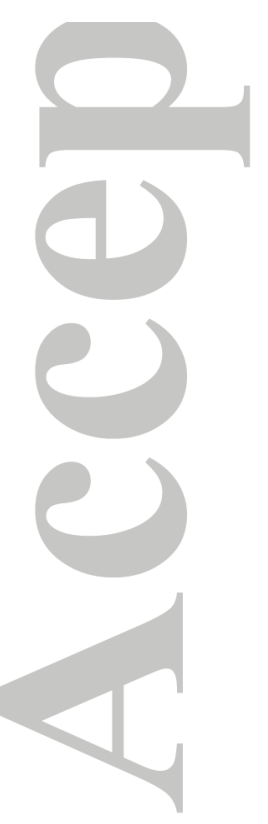

Wiley-Blackwell and Society for Applied Microbiology

This article is protected by copyright. All rights reserved. 

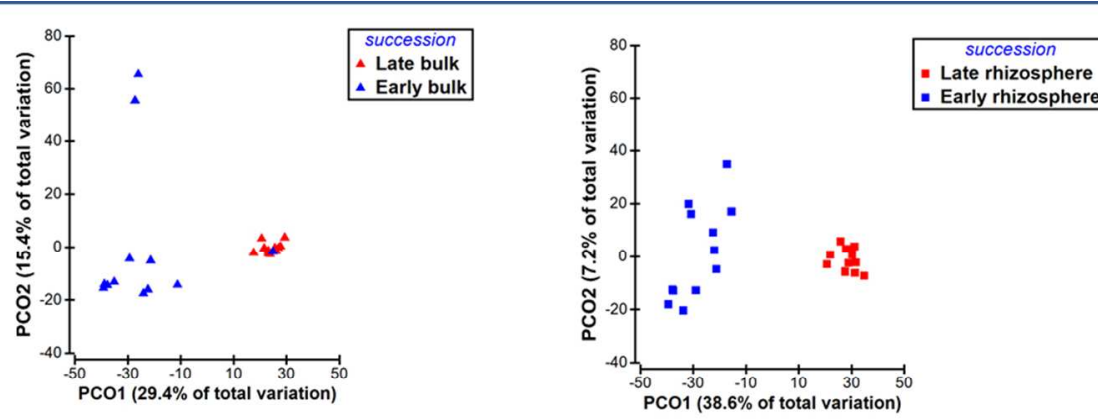

Late bulk
Early bulk

- Early rhizosphere

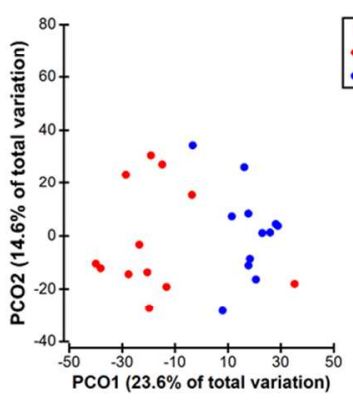

succession
- Late leaf

- Early leaf

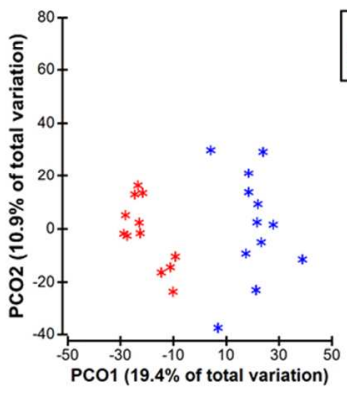

Figure 2.1

Figure 2.1

$290 \times 196 \mathrm{~mm}(96 \times 96 \mathrm{DPI})$

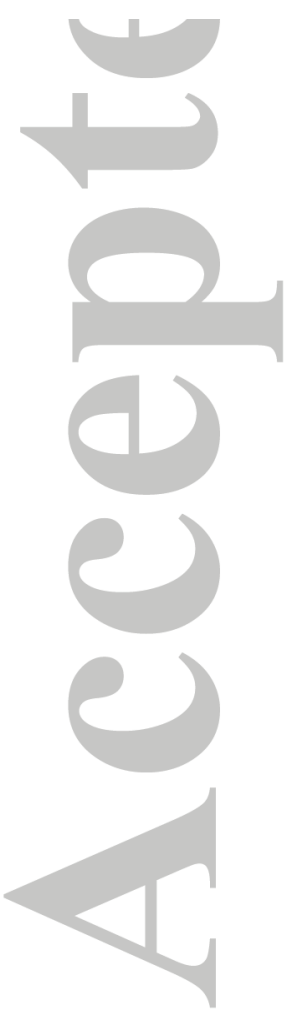

Wiley-Blackwell and Society for Applied Microbiology

This article is protected by copyright. All rights reserved. 

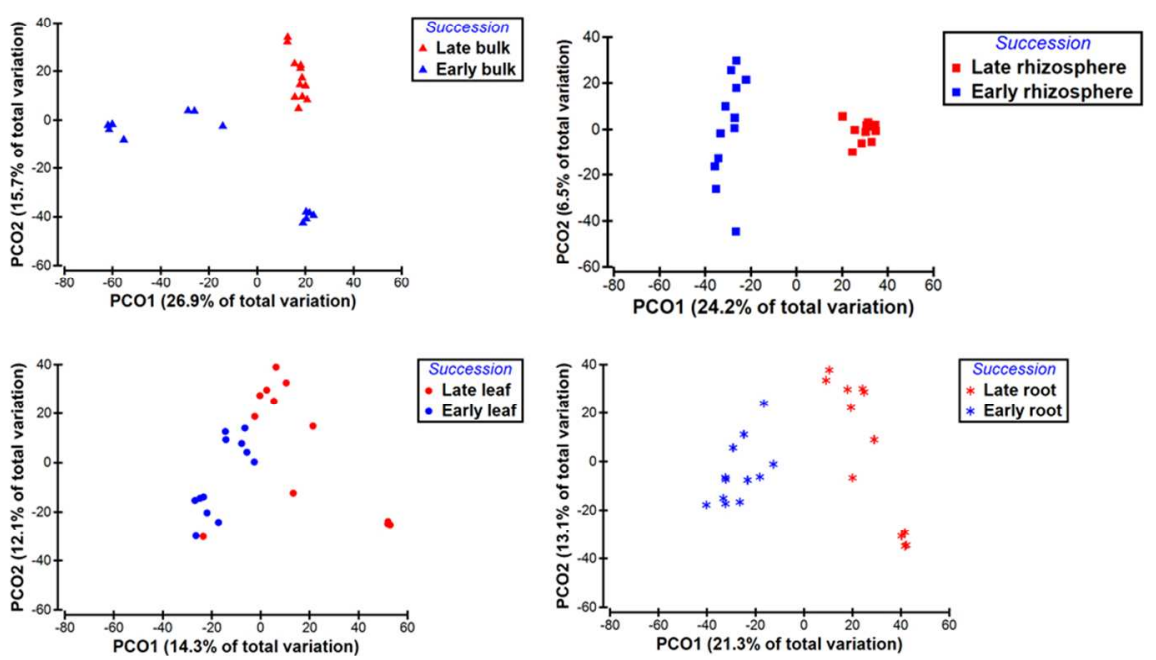

Figure 2.2

Figure 2.2

$290 \times 196 \mathrm{~mm}(96 \times 96 \mathrm{DPI})$

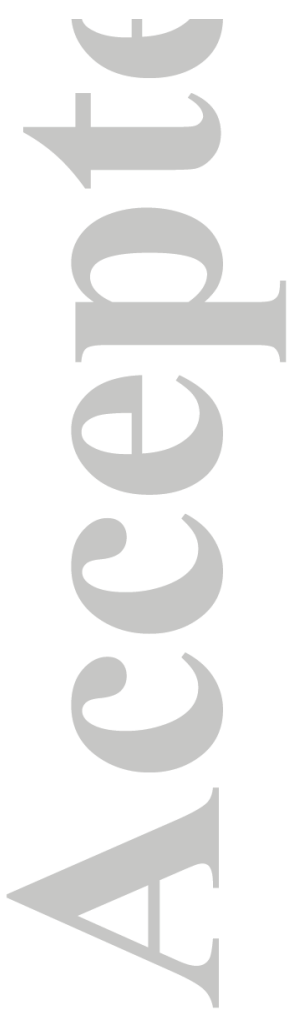

Wiley-Blackwell and Society for Applied Microbiology

This article is protected by copyright. All rights reserved. 


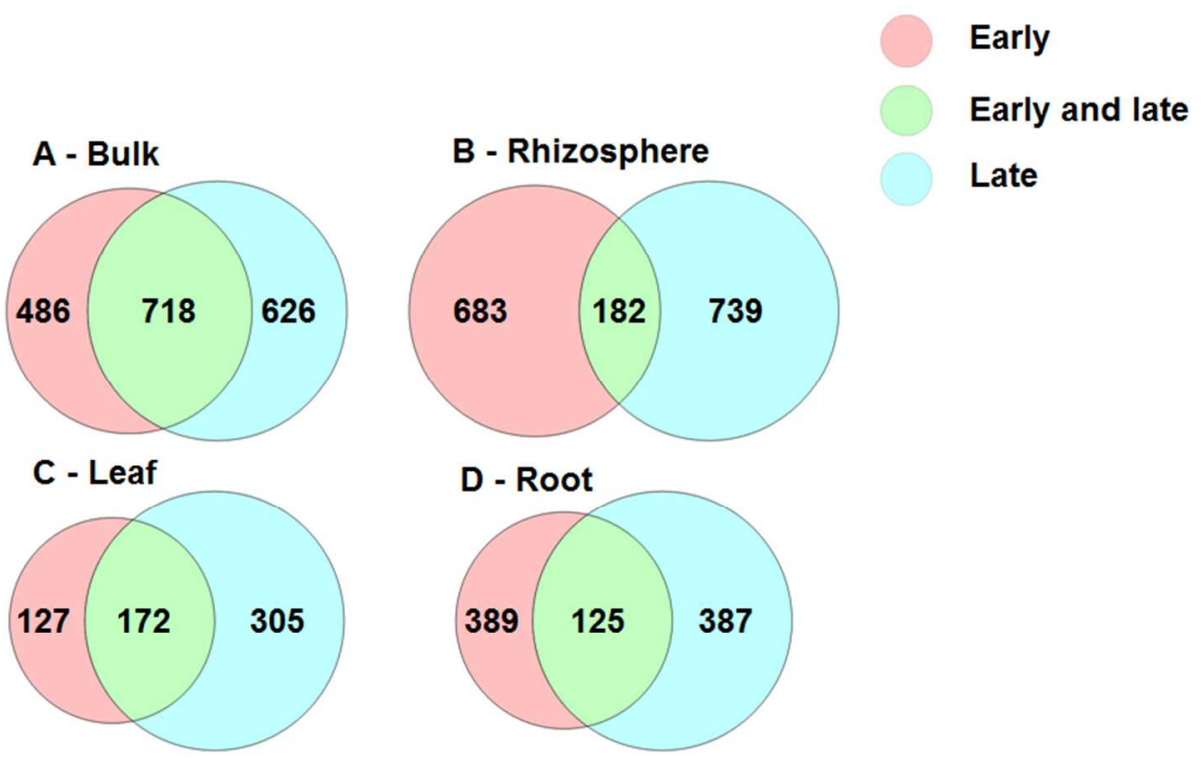

Figure 3

$243 \times 141 \mathrm{~mm}(96 \times 96 \mathrm{DPI})$

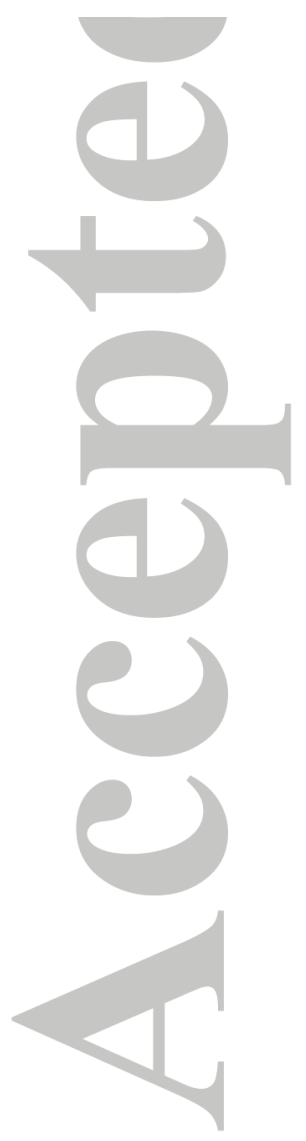

Wiley-Blackwell and Society for Applied Microbiology

This article is protected by copyright. All rights reserved. 


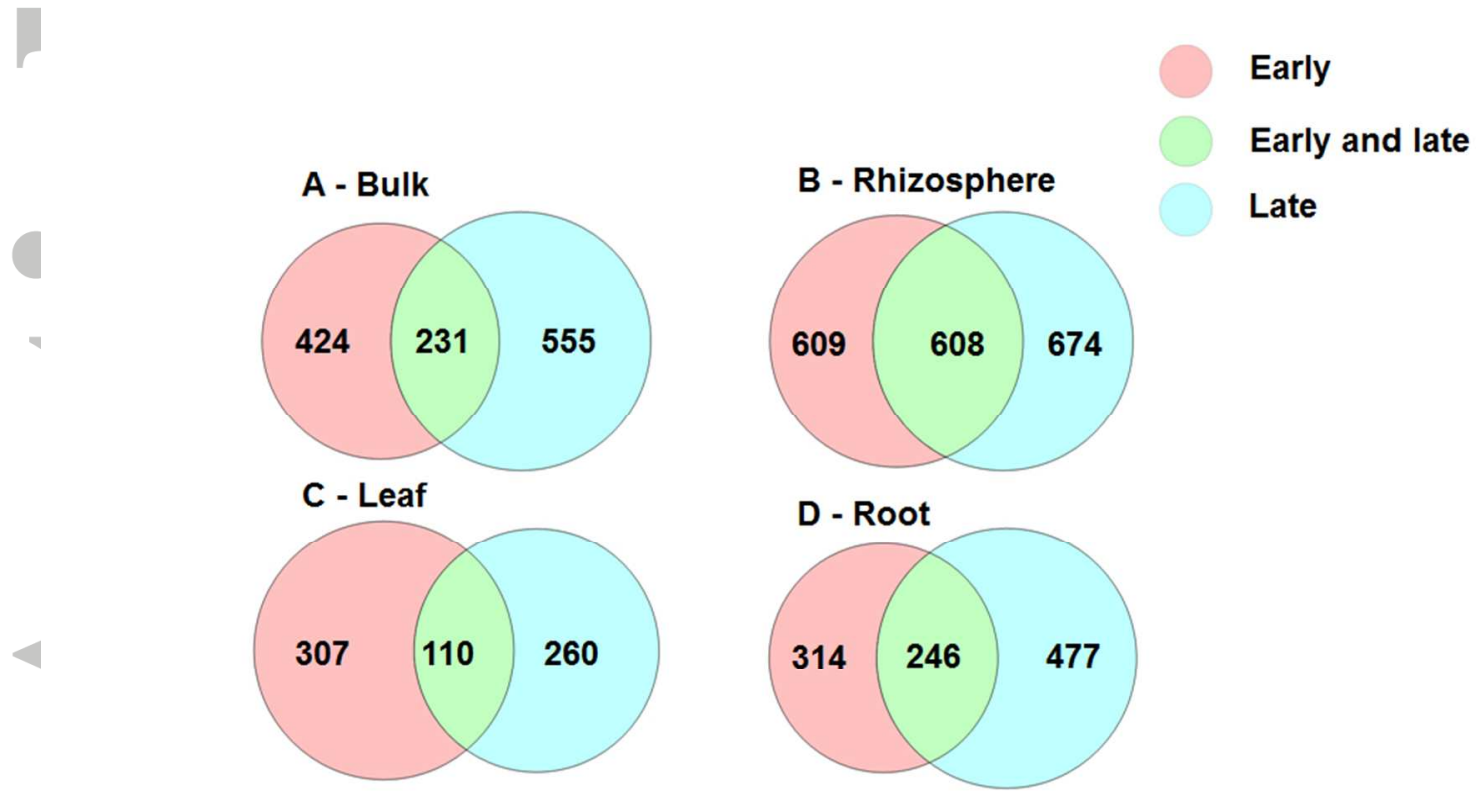

Figure 4

$243 \times 142 \mathrm{~mm}(96 \times 96$ DPI)

Wiley-Blackwell and Society for Applied Microbiology

This article is protected by copyright. All rights reserved. 